\title{
Foreign Direct Investment on Agricultural Industry in India
}

\author{
M.Gurupandi, S.Eswaran
}

\begin{abstract}
Agriculture is the primary source of livelihood for about 58 per cent of India's population. Gross Value Added by agriculture, forestry and fishing is estimated at Rs 18.53 trillion (US\$ 271.00 billion) in FY18. According to the Department for Promotion of Industry and Internal Trade (DPIIT), the Indian food processing industry has cumulatively attracted Foreign Direct Investment (FDI) equity inflow of about USD 9.08 billion between April 2000 and March 2019. The agriculture sector in Asian country is anticipated to come up with higher momentum within the next few years thanks to accrued investments in agricultural infrastructure like irrigation facilities, deposit and cold storage. What is more, the growing use of genetically changed crops can probably improve the yield for Indian farmers. India is anticipated to be self-sustaining in pulses within the returning few years because of conjunctive efforts of scientists to urge early-maturing types of pulses and therefore the increase in minimum support value. FDI works as a way of integration developing countries into the world market place and increasing the capital accessible for investment, so resulting in inflated economic process required to cut back financial condition and lift living standards. India is expected to achieve the ambitious goal of doubling farm income by 2022. This study main objective is analyzing Indian agricultural manufacturing and allied industries are qualified for the future expansion of agriculture sector through its modernization of agro based machineries industries. This study centered solely the chances of the allied industries (R\& D, equipments, and machineries up gradation.
\end{abstract}

Keywords : FDI, Agriculture, Investments, Agro Products, Warehousing.

\section{INTRODUCTION}

India is primarily an agrarian economy. While agriculture is estimated to account for just over 17 percent of the US\$2.6 trillion economy, the sector employees over 60 percent of the population. India has largely achieved self-sufficiency in production of food grains, delivering strong and fast economic growth for the past several years, and this trend is projected to continue in the future. The country has unique competitive advantages with the largest arable land area (60.44 percent) of an estimated 179.8 million hectares and diverse agro-climatic conditions supporting the cultivation

Revised Manuscript Received on September 25, 2019

* Correspondence Author

Dr.M.Gurupandi, Assistant Professor of Commerce, School of Management, Alagappa University, Karaikui-630004.

Mr.S.Eswaran, M.Phil Scholar in Commerce, Alagappa University, Karaikui-630004 of various crops. The agricultural sector indeed plays a vital role in Indian economics, politics, and society. India is among the highest-ranking countries in production volume for various commodities like rice, cotton, dairy, fruits, vegetables, meat and seafood, but the nation has access to only 60 percent of the produce due to lack of storage infrastructure, which leads to an estimated loss of up to 40 percent of the produce. In fact, these losses are estimated at $\$ 13$ billion annually. Over the past decade, agriculture and horticulture outputs have seen record growth year-after-year. Yet, crop yields are still generally lower compared to the world average. This low productivity is due to many factors such as erratic monsoons (over 50 percent of cultivated land is monsoon dependent), shrinking groundwater resources, decline in soil fertility, inefficiency in the food distribution system, lack of storage, transportation, lack of awareness in the use of modern agricultural practices and technologies among the farming community, unpredictable weather, small average farm sizes of 1.08 hectares, and agricultural subsidies that distort market signals and hamper productivity-enhancing investment.

The agricultural sector in Republic of India is witnessing a shift from ancient farming to organic farming, gardening, cultivation, poultry, and dairy farm production. The demand for contemporary and processed merchandise of all kinds is increasing thanks to speedy urbanization, the increase in incomes, and ever-changing consumption habits of the population. the expansion of associate degree economical cold chain network from "farm to fork" can facilitate curb the present spoilage rate of agricultural output whereas serving to producers capture worth as merchandise retain quality and provides further profit to customers.

India's food and grocery $(\mathrm{F} \& \mathrm{G})$ retail business is estimated at $\$ 380$ billion. The $\mathrm{F} \& \mathrm{G}$ retail sector is dominated by traditional trade formats like neighborhood shops or mom and pop stores, which hold about 98 percent of the total market share. The market share held by modern trade formats such as supermarkets and hypermarkets is expected to double from two to four percent by 2020 as stores fulfill the evolving needs of consumers. 


\section{Foreign Direct Investment on Agricultural Industry in India}

The Indian fiscal year (IFY) 2017-2018 has seen significant changes in the retail and e-retail space in India through the acquisition and takeover of several smaller formats of retail chains by larger domestic and international players in the food retail segment. The acquisition of Bengaluru headquartered e-retailer Flipkart by Walmart for $\$ 16$ billion stood out as the biggest acquisition by a foreign retailer in India.

Over the years, India has developed export competitiveness in certain specialized products, making it the world's 14th largest agricultural, fishery, and forestry product exporter. In 2018, India accrued a $\$ 14.6$ billion trade surplus of agricultural, fishery, and forestry goods. Leading exports consisted of Basmati rice, carabeef/meat of bovine animals, frozen shrimp and prawns, cotton, and refined sugar

\section{LEADING SUB-SECTORS OF AGRICULTURAL INDUSTRY}

\section{Agricultural Machinery}

India is the largest tractor market in the world and is estimated to grow at 10 percent annually for the foreseeable future. It is estimated that tractor production in India accounts for about 35 percent of global volumes. The major market share is garnered by the 31-50 hp segment which accounts for 82 percent of sales volumes of 711,478 units in 2018 . However, the utilization of tractors is low compared to other leading economies of the world. Although tractors are the core of farm mechanization, farm production has gone way beyond simply utilizing tractors. A stronger emphasis now is on increasing productivity by moving away from traditional farming methods to adopting other powered equipment and implements, thus becoming a prime driver of growth in this sector. In addition, the government is working to provide easier access to credit for farmers, developing farmer-friendly policies, tying into the new and growing trend of collaborative farming in India.

Various state governments, with support from the federal, have commenced a public-private partnership model to start out custom for-hire centers to supply agricultural machinery/implements on a rental basis to farmers, therefore easing the employment of mechanization and gap opportunities for used instrumentation exporters. this can be a key modification, as buying the instrumentation is on the far side the reach of the many farmers because of high acquisition and maintenance prices, and therefore the average size of farms in Asian country is a smaller amount than 2 hectares.

The key growth drivers are going to be farmers exchange previous tractors with new energy economical ones, the expansion of tractors in low-density regions across the country, and non-farm usage like pull within the construction and road building sector. Hence, there's growth potential given the dimensions and importance of agriculture within the Indian economy.

\section{Irrigation}

The Indian government has laid out an ambitious goal of doubling farmers' incomes by 2022. To achieve this ambitious goal, the Indian government is aggressively promoting rural development with an impetus on agricultural mechanization and irrigation penetration. The government is allocating funds to these initiatives, which are critical components in improving the state of agriculture in the country. Agriculture in India is vulnerable to the vagaries of weather because an estimated 52 percent of farm land is unirrigated and still dependent on rainfall. India receives sporadic rainfall across the region, and farmers are flooding their fields, which results in wastage of precious water. Efficient usage of water is critical to Indian agriculture as the demand for water for irrigation will steadily rise due to the enormous population. The key drivers of growth for irrigation equipment/machines will primarily be population growth, food scarcity and shortage of water. American companies providing energy efficient affordable irrigation products may have business opportunities to explore in the India market.

\section{Farming-as-a-Service (FaaS)}

Farming-as-a-Service is a concept which was spawned a few years ago in India by offering farming services, machinery, and implement rentals on a pay-per-use basis. The concept is still in its nascent stage but is becoming popular, and a handful of local startups have begun operations in the market. Farming services such as land preparation, soil-health data, sowing, harvesting, crop management, post-harvest management, and machinery rental will be relevant to most of the farmers as they own small farmlands (average size 1.15 hectares) which are affordable and reduce the need for capital expenditure.

\section{Food Processing Sector}

The food processing sector in India is one of the largest sectors, accounting for 32 percent of the country's total food market. The sector is the sixth largest and ranks fifth in terms of production, consumption, exports and growth. The sector contributes 9 percent and 11 percent of GDP in manufacturing and agriculture, respectively, and makes up for 13 percent of India's exports and 6 percent of total industrial investment. As per the 
latest Annual Survey of Industries, there are 39,319 registered food processing units in the country that employ approximately 1.7 million people in food and beverage manufacturing.

India has established itself as a web food businessperson with a homogenous balance of trade surplus in food and agricultural product. tho' the country remains prone to production and worth shocks for numerous commodities, the food process sector is growing at a median rate of eight p.c once a year. it's expected to any grow thanks to increase in domestic consumption, ever-changing trends in markets, shopper preferences for added product and growing capabilities.

India ranks second in terms of global food production and are the world's largest producer of many commodities. However, compared to global trends, a negligible amount of produce is processed in India due to key challenges such as a lack of advanced processing technologies, market disconnects and a lacking supply chain infrastructure. Food wastage remains a critical challenge, and an estimated 40 percent of perishable produce goes to waste.

The Government of India has plans to reduce wastage of agricultural produce by 50 percent in the next two years. To address some rising concerns of food wastage and positioning the country as the food processing hub, the government is facilitating policy reforms, capital subsidies, tax rebates, reduced custom duties and access to credit for entrepreneurs establishing food processing units. The Ministry of Food Processing Industries (MoFPI) has implemented and sanctioned the establishment of 42 mega food parks in the country, with nine operationalized under the scheme as of 2018. Though food policy reforms suggest progress, import of non-standardized foods and ingredients remains a challenge owing to regulatory and tariff barriers. While opportunities for imported food in the Hotel, Restaurant \& Institutional (HRI) and food processing sectors are improving, the India market remains relatively small due to high tariffs, ongoing import restrictions, and strong competition from the domestic industry.

\section{OBJECTIVES OF THE STUDY}

- To study the key driving factors and challenges in the Indian agricultural equipments market

- To analyze the structure of the Indian agricultural equipments market and who are the key players

- To find the degree of competition in the Indian agricultural equipments market

\section{REVIEW OF LITERATURE}

\section{Sunil Kumari and Preeti Devi (2016)}

Foreign Direct Investment on Indian Agriculture" Agriculture plays an important role in economic development of India. The contribution of agricultural sector to national Gross Domestic Product (GDP) has continued to decline over the years, while that of other sectors. Presently, agriculture contributes $19 \%$ per cent of India's Gross Domestic Product (GDP). Agriculture is the main part of the Indian economy as it forms the backbone of rural India which inhabitants more than $70 \%$ of total Indian population. Most of the rural population in India depends on agricultural sectors for employment and livelihood. $100 \%$ FDI is also permitted in tea sector, FDI is not allowed in any other agricultural sector/ activity. The present study is based on secondary data collected through different sources. The objective of the present study is to analyze the foreign direct investment on Indian agriculture. The paper focuses on the FDI and agriculture sector in Indian economy and compares the FDI in agriculture sector with other sectors in India. This paper also tries to find out the scenario and impact of Foreign Direct Investment on Indian agriculture. It also shows that there has been a remarkable increase in FDI inflows in agriculture sector in India during the year 2000 to 2015 .

Epaphra, M (2017) “Analysis of Foreign Direct Investment, Agricultural Sector and Economic Growth in Tanzania" This paper analyzes the effect of foreign direct investment (FDI) on agricultural sector in Tanzania. The paper also examines the declining contribution of agriculture to real GDP growth despite the fact that the sector employs more than 70 percent of the total labour force. Annual time series data spanning from 1990 to 2015 are used to test the significance of the relationship between FDI inflow and agriculture value added-to-GDP ratio on one hand and FDI inflows and economic growth on the other hand. Also, the relationship between agriculture value added and economic growth rate is empirically examined. Variables such as gross fixed capital formation, inflation rate, trade liberalization, real exchange rate and population are considered as control variables. For the purpose of inference, the paper employs classical linear regression model. Ordinary least squares methods are used for estimation. The diagnostic tests including RESET regression errors specification test, Breusch-Godfrey serial correlation LM test, Jacque-Bera-normality test and white heteroskedasticity test reveal that the models have no signs of misspecification and that, the residuals are serially uncorrelated, normally distributed and homoskedastic. Interestingly, empirical results suggest that there is no significant effect of FDI inflows on agriculture value added-to-GDP ratio in Tanzania despite the fact that FDI inflows in 
economy have been outstanding particularly in past two decades. Unsurprisingly, the results show that FDI inflows-to-GDP ratio and real GDP growth rate are positively correlated. Notwithstanding, agriculture sector, which constitutes the largest proportion of the total labour force, contributes, on average, less than 30 percent, to total GDP. This suggests that the sector is inefficient and therefore, effort towards attracting more FDI aiming at improving productivity in agriculture sector, which in turn may reduce poverty, is much needed.

\section{Indian Agricultural Equipment Market: Drivers}

Labour Shortage: Labour shortage has been a serious reason that has driven farmers towards farm mechanization. giant scale migration from rural to urban areas and variety of rural employment schemes has created a labour shortage in rural areas. for example, the National Rural Employment Guarantee Agency (NREGA) has had in several places a ripple result - labour shortage resulting in farm mechanization. The implementation of this theme has considerably reduced the influx of seasonal migrant labourers from Bihar and UP to states like Haryana and Punjab throughout the crucial sowing and transplantation season. As a result, has witnessed a big increase.

Ease of Financing: In recent years, variety of banks and microfinance establishments are set all across rural Bharat. This has provided farmers a simple accessibility of credit to get farm machinery.

Government Incentives: Incentives in the form of subsidies, low import duties on agricultural machinery and easy financing schemes by the Indian government has also been a major driver of the farm equipments market in India.

Rising incomes: As a result of strong economic growth and agricultural productivity, the income levels of rural households have been continuously increasing over the last few years. Rising incomes have enabled farmers to significantly increase their spending on agriculture mechanization.

Large Untapped Market: Despite strong growth in recent years, the penetration of tractors and a number of related equipments still remains relatively low. This is expected to leave a lot of room for future growth.

Emergence of Contract Farming: The emergence of contract farming is also expected to give a strong boost to the agricultural equipments market in India. We expect contract farming to enable farmers to get the benefit of technology, training and financing with the contractor's support. This is expected to facilitate the adoption of mechanized farming practices. the demand for farm machines in these states

\section{FDI INFLOWS TO AGRICULTURE SECTOR}

The FDI Inflows to Agriculture Services are allowed up to $100 \%$ and allowed through the automatic route covering horticulture, floriculture, development of seeds, animal husbandry, pisciculture, aqua culture, cultivation of vegetables, mushroom and services related to agro and allied sectors. Only in Tea sector, 100\% FDI is allowed, including, plantations of tea.

In India, agriculture is an important sector of the Indian economy and accounts for almost $19 \%$ of Indian gross domestic products (GDP). Agriculture is the main stay of the Indian economy as it forms the backbone of rural India which inhabitants more than $70 \%$ of total Indian population.

The Ministry of Agriculture, the Ministry of Rural Infrastructure, and the Planning Commission of India are the main governing bodies that define the future role of agriculture in India and it aims at developing agricultural sector of India. No FDI / NRI / OCB is allowed in the Indian Agriculture sector. Only in Tea sector $100 \%$ FDI is allowed, including plantations of tea. This requires Government of India approvals. Further, it requires compulsory divestment of $26 \%$ equity in favor of the Indian partner or Indian public within a maximum period of five years. This also requires approval from the concerned state government in case of change in use of land for such activities. And this holds true for any fresh investments in the above-mentioned sector.

FDI in Indian agriculture sector and the latest developments are as follows:

- Telecommunications, services and computer software were the top areas attracting foreign direct investment (FDI) in India during the first quarter of the on-going fiscal. The total inflows into all sectors increased by 28 per cent to $\$ 16.33$ billion, according to government figures.

- In last fiscal, the FDI inflow during the first quarter was $\$ 12.75$ billion in the comparable period.

- Singapore was the largest source of FDI in India in the April-June 2019-20 period with \$ 5.33 billion investments followed by FDI from Mauritius worth \$4.67 billion, the US worth \$ 1.45 billion, the Netherlands worth \$ 1.35 billion and Japan worth \$ 472 million.

- While telecommunications emerged as the top sector in April-June 2019-20, attracting FDI worth $\$ 4.22$ billion, services sector (which includes financial, banking, insurance, non-financial business, outsourcing, R\&D, 
courier and technology testing and analysis) was in the second position with FDIs worth \$ 2.8 billion. This was followed by computer software and hardware with \$2.24 billion and trading with \$ 1.13 billion, as per the data released by the Commerce and Industry Ministry.

- Delhi and parts of Haryana as well as Uttar Pradesh (UP), attracted the maximum FDI in the first quarter of 2019-20 at \$ 5.04 billion. It was followed by Karnataka with FDI worth \$ 3.01 billion, Ahmedabad with FDI worth \$ 2.6 billion and Maharashtra with FDI worth \$ 1.56 billion.

- In 2018-19, India attracted FDIs worth $\$ 44.36$ billion which was marginally lower than FDIs attracted in 2017-18, which were worth $\$ 44.85$ billion.

- Last month, the Central Government had announced certain relaxations in the FDI policy in sectors such as single-brand retail, contract manufacturing and coal mining, in the hope of making the regime more attractive and increasing investment flows.

- A pilot programme for delivering subsidy directly to farmers have been arranged Loan facilitation through Agricultural Insurance and NABARD has also been facilitated

- Corpus of Rural Infrastructure Development Fund to be raised

FDI Inflows to Agriculture Services also facilitated growth of other allied areas, like the following:

- Irrigation

- Roads

- Housing

- Water Supply

- Electrification

- Telecommunication Connectivity

FDI Inflows to Agriculture Services has effected development of rural infrastructure, like

- To connect 66,800 habitations with population over 1000 with all weather roads

- To construct $1,46,000 \mathrm{Km}$ of new rural roads

- To upgrade and modernize $1,94,000 \mathrm{Km}$ of existing rural roads

- Total investment of - 1,74,000 crore envisaged under "Bharat Nirman", investment on rural roads estimated to be at `48,000 crore

- To provide corpus of - 8000 crore to Rural Infrastructure Development Fund (RIDF)

\section{Role of the Agriculture in Indian economy:}

India is second most populous country in the world. Majority of its population lives in villages and earns their livelihood through farming.
Agriculture is the backbone of Indian economy. It contributes around $22 \%$ of the total GDP. $65 \%$ of Indian population lives mainly in its 600,000 villages. Agriculture is the mainstay of the majority of the villagers as they are employed in agriculture or agriculture related services. Presence of diverse agro climate zones and a variety of soil and agro-climatic conditions have made possible the cultivation of almost every item from cash crops to food grains. The Agriculture sector provides livelihood to about $65 \%$ of the labor force and accounts for $8.56 \%$ of India's exports. After USA, India has maximum area of arable land but productivity per hectare is nowhere near the world best. India is not in the top ten countries in terms of productivity of rice and wheat. Despite green revolution Indian agriculture sector has not been able to achieve the world level productivity. Cardinal reasons behind this are highly fragmented nature of Indian farming with close to $33 \%$ of arable land held in units of less than 2 hectares per owner. It doesn't let farmers enjoy the economies of scale in operations and modern farming equipment proves very expensive for them. Low quality is also a problem. So there is a need to look for interventions that can help the farmers realize higher level of income

\section{FDI Equity inflows in Agricultural Machinery} Sector from 2000-01 to 2016-17

In Agricultural Machinery sector from 2000-01 to 2016-17, there was a FDI Equity inflow of USD 3.64 million, USD 1.04 million, USD 13.48 million, USD 47.54 million, USD 0.00 million, USD 92.71 million, USD 25.19 million, USD 6.72 million, USD 5.57 million, USD 1.88 million, USD 0.49 million, USD 2.77 million, USD 95.41 million, USD 48.78 million, USD 72.35 million, USD 16.44 million and USD 15.19 million respectively. During the year 2012-13, there was a huge FDI Equity inflow in Agricultural Machinery sector, i.e., USD 95.41 million. There was an annual growth of $48.32 \%$ in FDI Equity inflow in this sector during 2014-15 over 2013-14. There was an annual de-growth of $-77.28 \%$ in FDI Equity inflow in this sector during 2015-16 over 2014-15. We have observed an annual decline of $-7.6 \%$ in FDI Equity inflow in this sector during 2016-17 over 2015-16.

The growth in manufacturing sector picked up in 2018-19, although the momentum slowed down towards the end of the financial year with a growth of 3.1 per cent in fourth quarter of the year, as compared to 12.1 per cent, 6.9 per cent and 6.4 per cent in first, second and third quarter respectively. The growth rate in Q4 of 2018-19 moderated considerably, on account of 
lower NBFC lending, which in part led to sales in the auto sector.

Growth in the industry accelerated during 2018-19 on the strength of improving manufacturing and construction activity, which have more than offset the declaration in the other two sub sectors, 'Mining \& quarrying' and 'Electricity, gas, water supply \& other utility services'. Manufacturing accounted for 16.4 per cent in total GVA in 2018-19, marginally higher than that of 'Agriculture \& allied' sector.

\section{India Agricultural Equipment Industry:}

The industry research publication on India Agricultural Equipment Industry Outlook to 2018 - Growing Potential of Rice Transplanters Market provides comprehensive analysis of market size of farm equipments such as tractors (50HP), combine harvesters (wheel type self propelled, tractor mounted, track type self propelled), rice transplanters, rotavators, power tillers and threshers in India. The report provides market share analysis of major players in tractor, rotavator, power tillers, and rice transplanters and threshers market along with the company profile. The publication provides trends and development, average prices, future outlook and prospects of farm equipments along with the cause and effect relationship of several macro-economic and industry factors.

The Indian agriculture sector has witnessed a substantial decline within the use of human and animal power for agricultural activities in recent years. This has paved how for a variety of agricultural equipments that are introduced within the market. an oversized variety of those agricultural equipments are driven by tractors or diesel engines and so are fleetly reworking the normal agricultural processes of the country into agriculture mechanization.

\section{Indian Agricultural Equipment Market}

The Indian agricultural equipment market was worth INR 908 Billion in 2018. The market is further projected to reach a value of INR 1,289 Billion by 2024, growing at a CAGR of $6 \%$ during 2019-2024. Over the last few years, there has been a considerable progress in agriculture mechanization. A significant proportion of farmers in the country have already started moving from using animate sources to mechanical equipments to power their farming activities. Mechanical equipments for numerous farm operations like tillage, sowing, irrigation, plant protection and separation, etc., area unit typically being employed by the farming community. As a result of increasing farm mechanization trends, the agricultural instrumentation market has witnessed robust growth within the past few years. This market is presently being driven by variety of things like simple accessibility of credit, government incentives, increasing agricultural productivity, emergence of contract farming, increasing rural incomes, etc.

\section{Indian Agricultural Equipment Market: Drivers}

Labour Shortage: Labour shortage has been a major reason that has driven farmers towards farm mechanization. Large scale migration from rural to urban areas and a number of rural employment schemes have created a labour shortage in rural areas. For instance, the National Rural Employment Guarantee Agency (NREGA) has had in many places a ripple effect - labour shortage leading to farm mechanization. The implementation of this scheme has significantly reduced the inflow of seasonal migrant labourers from Bihar and UP to states like Haryana and Punjab during the crucial sowing and transplantation season. As a result, the demand for farm machines in these states has witnessed a significant increase.

Ease of Financing: In recent years, a number of banks and microfinance institutions have been set all across rural India. This has provided farmers an easy availability of credit to purchase farm machinery.

Government Incentives: Incentives in the form of subsidies, low import duties on agricultural machinery and easy financing schemes by the Indian government has also been a major driver of the farm equipments market in India.

Rising incomes: As a result of strong economic growth and agricultural productivity, the income levels of rural households have been continuously increasing over the last few years. Rising incomes have enabled farmers to significantly increase their spending on agriculture mechanization.

Large Untapped Market: Despite strong growth in recent years, the penetration of tractors and a number of related equipments still remains relatively low. This is expected to leave a lot of room for future growth.

Emergence of Contract Farming: The emergence of contract farming is also expected to give a strong boost to the agricultural equipments market in India. We expect contract farming to enable farmers to get the benefit of technology, training and financing with the contractor's support. This is expected to facilitate the adoption of mechanized farming practices.

India has the 10th-largest arable land resources in the world. With 20 agri-climatic regions, all 15 major climates in the world exist in India. The country also possesses 46 of the 60 soil types in the world. India is the largest producer of spices, pulses, milk, tea, cashew and jute; and the second largest producer of wheat, rice, fruits and vegetables, sugarcane, cotton and oilseeds. 
Further, India is second in global production of fruits and vegetables, and is the largest producer of mango and banana. During 2017-18 crop year, food grain production is estimated at record 284.83 million tonnes. In 2018-19, Government of India is targeting foodgrain production of 285.2 million tonnes. Production of horticulture crops is estimated at 306.82million tonnes (mt) in 2017-18 as per third advance estimates. India is among the 15 leading exporters of agricultural products in the world. Agricultural exports from India reached US\$ 38.21 billion in FY18 and US\$ 38.54 billion in FY19. Exports of ready to eat items from India reached US\$ 689.80 million in FY18 and have reached US\$ 681.95 million in FY19. The Agriculture Export Policy, 2018 was approved by Government of India in December 2018. The new policy aims to increase India's agricultural exports to US\$ 60 billion by 2022. India was the ninth largest exporter of agricultural products in 2017.

The Electronic National Agriculture Market (eNAM) was launched in April 2016 to create a unified national market for agricultural commodities by networking existing Agriculture Produce Marketing Committees (APMCs). Up to May 2018, 9.87 million farmers, 109,725 traders were registered on the e- NAM platform. 585 mandis in India have been linked while 415 additional mandis will be linked in 2018- 19 and 2019-20. Cumulative trade on the platform reached Rs 41,855 crore (US\$ 6.49 billion) by March 2018. The Budget 2019 has identified Agriculture Sector as one of the key drivers of the economy. Under the budget Agricultural Marketing Infrastructure (AMI) scheme 40 lakh MT of storage capacity \& 400 other marketing Infrastructure projects are targeted by 2019-20.

The Government of India has introduced several projects to assist the agriculture sector. They are Pradhanmantri Gram Sinchai Yojana The scheme aims to irrigate the field of every farmer and improving water use efficiency to achieve the motto 'Per Drop More Crop'. Overall the scheme ensures improved access to irrigation. Around 285 new irrigation projects will be undertaken in 2018 to provide irrigation for 18.8 million hectares of land. As per Union Budget 2019-20 the scheme has been allocated US\$ 565.16 million.

\section{Competition issues in the agricultural sector in India} market wherever we've got several suppliers and patrons of a similar product we tend to don't see any competition among the farmers or among the patrons. The market costs are not maintained by a personal it's maintained by the mandis on the idea of demand and provide.
Practically speaking as agriculture could be a

however once checking out a similar I found this text useful.

Economic theory typically describes Associate in Nursing business as either experiencing excellent competition or one among many types of imperfect competition. Production agriculture is usually used as Associate in Nursing example of Associate in Nursing business with excellent competition; that's, "your wheat will substitute for my wheat." though this could be correct for several segments of production agriculture, an issue is whether or not this can be dynamic. can production agriculture remodel into Associate in Nursing business of less-than-perfect competition.

\section{Characteristics of Perfect Competition}

The following list summarizes the characteristics of a perfectly competitive market:

- homogenous product (one seller's product can easily be substituted with or replaced by the another seller's product),

- many buyers and sellers (buyers can easily find replacement sellers and sellers can generally find replacement buyers),

- $\quad$ full (readily available) information (about market opportunities and production technology),

- easy entrance and exit (i.e., easy to start or discontinue producing the product), and

- Mobile resources (easy to move resources from this industry to an alternative use).

As a result of perfect competition, sellers have limited opportunity to earn an economic profit.

- Conversely, an industry that lacks one or more characteristics of perfect competition is considered to be facing imperfect competition and have an opportunity to earn more than a minimal return.

- Does this outcome suggest that a business person should intentionally try to "eliminate" one or more characteristics of perfect competition so the business has an opportunity to increase its earnings

\section{Factors that influence the level of competition:}

- Information technology increases the availability of information; e.g., market information for sellers and buyers, and information about production techniques.

- Access to new production technology, whether the firm is raising livestock, baking bread, or transporting oranges. Is the new technology available to all businesses, or is the technology controlled and accessible to only some of the businesses? 


\section{Foreign Direct Investment on Agricultural Industry in India}

- Advancing transportation technology (as well as processing, storage, packaging, and other technologies) allows businesses to move products around the world thereby increasing the number of buyers and sellers in a market.

\section{Competition in agricultural products}

1. organic agriculture: This segment of agriculture have some competetion as the certified farmers are less in number and have growing buyers in the higher or bigger mandis. But in smaller mandis we dont find good buyers of organic products.

2. Varieties where quality is given more importance than quantity.

3. Agriculture of endangered species: Recently i was reading a news where a farmer sold his produce of wheat at 5000 rs per quintle as he had grown endangered species with some medicinal properties so he was able to fetch rs 50 per Kg instead of 15-20 rs per $\mathrm{Kg}$ of the normal variety.

4. Export material: If you are into exports in agriculture you can have competetion around with international bodies producing the same products for the quality and maintaining the market.

\section{TYPES OF AGRO-BASED INDUSTRY}

1. Cotton textiles

2. woollen textiles

3. Silk textiles

4. Synthetic fibres

5. Jute textile industries

Textile Industry

It occupies unique position in the Indian economy, because it contributes significantly to industrial production (14 per cent), employment generation (35 million persons directly - the second largest after agriculture) and foreign exchange earnings (about 24.6 per cent). It contributes 4 per cent towards GDP. It is the only industry in the country, which is self-reliant and complete in the value chain i.e., from raw material to the highest value added products.

\section{Cotton Textiles}

In ancient India, cotton textiles were produced with hand spinning and handloom weaving techniques. After the 18th century, power-looms came into use. Our traditional industries suffered a setback during the colonial period because they could not compete with the mill-made cloth from England. Today, there are nearly 1600 cotton and human made fibre textile mills in the country.

About 80 per cent of these are in the private sector and the rest in the public and cooperative sectors. Apart from these, there are several thousand small factories with four to ten looms. In the early years, the cotton textile industry was concentrated in the cotton growing belt of Maharashtra and Gujarat. Availability of raw cotton, market, transport including accessible port facilities, labour, moist climate, etc. contributed towards its localisation. This industry has close links with agriculture and provides a living to farmers, cotton boll pluckers and workers engaged in ginning, spinning, weaving, dyeing, designing, packaging, tailoring and sewing.

The trade by making demands supports several alternative industries, such as, chemicals and dyes, mill stores, packaging materials and engineering works. whereas spinning continues to be centralized in geographical area, Gujarat and state, weaving is extremely localized to supply scope for incorporating ancient skills and styles of weaving in cotton, silk, zari, embroidery, etc.

India has world category production in spinning, however weaving provides calibre of material because it cannot use abundant of the prime quality yarn created within the country. Weaving is finished by loom, loom and in mills. The hand spun khaddar provides giant scale employment to weavers in their homes as a manufacture.

India exports yarn to Japan. Other importers of cotton goods from India are U.S.A., U.K., Russia, France, East European countries, Nepal, Singapore, Sri Lanka, and African countries. India has the second largest installed capacity of spindles in the world, next to China, at around 34 million (2003-04). Since the mid-eighties, the spinning sector has received a lot of attention.

We have a large share in the world trade of cotton yarn, accounting for one fourth of the total trade. However, our trade in garments is only 4 per cent of the world's total. Our spinning mills are competitive at the global level and capable of using all the fibres we produce. The weaving, knitting and process units cannot use abundant of the top quality yarn that's made within the country. There ar some massive and trendy factories in these segments, however most of the assembly is in fragmented tiny units, that cater to the native market. This couple could be a major downside for the trade. As a result, several of our spinners export cotton yarn whereas apparel/garment manufactures got to import material.

\section{Jute Textiles}

India is the largest producer of raw jute and jute goods and stands at second place as an exporter after Bangladesh. There are about 70 jute mills in India. Most of these are located in West Bengal, mainly along the banks of the Hugli river, in a narrow belt $(98 \mathrm{~km}$ long and $3 \mathrm{~km}$ wide). Factors responsible for their location in the Hugli basin are: proximity of the jute manufacturing 
areas, cheap water transport, supported by an honest network of railways, roadways and waterways to facilitate movement of stuff to the mills, ample water for process raw jute, low cost labour from state and abutting states of state, Orissa and Uttar Pradesh. urban center as an oversized urban centre provides banking, insurance and port facilities for export of jute merchandise.

The jute industry supports 2.61 lakh workers directly and another 40 lakhs small and marginal farmers who are engaged in cultivation of jute and Mesta. Many more people are associated indirectly. Challenges faced by the industry include stiff competition in the international market from synthetic substitutes and from other competitors like Bangladesh, Brazil, Philippines, Egypt and Thailand. However, the internal demand has been on the increase due to the Government policy of mandatory use of jute packaging. To stimulate demand, the products need to be diversified. In 2005, National Jute Policy was formulated with the objective of increasing productivity, improving quality, ensuring good prices to the jute farmers and enhancing the yield per hectare. The main markets are U.S.A., Canada, Russia, United Arab Republic, U.K. and Australia. The growing global concern for environment friendly, biodegradable materials has once again opened the opportunity for jute products.

\section{Sugar Industry}

India stands second as a world producer of sugar but occupies the first place in the production of gur and khandsari. The raw material used in this industry is bulky, and in haulage its sucrose content reduces. There are over 460 sugar mills in the country spread over Uttar Pradesh, Bihar, Maharashtra, Karnataka, Tamil Nadu, Andhra Pradesh and Gujarat along with Punjab, Haryana and Madhya Pradesh. Sixty per cent mills are in Uttar Pradesh and Bihar. This industry is seasonal in nature so, it is ideally suited to the cooperative sector. In recent years, there's an inclination for the mills to shift and concentrate within the southern and western states, particularly in Maharashtra; this can be as a result of the cane created here has higher disaccharide content. The cooler climate additionally ensures a extended crushing season. Moreover, the cooperatives ar a lot of self-made in these states. Major challenges embrace the seasonal nature of the business, recent and inefficient ways of production, transport delay in reaching cane to factories and also the got to maximize the employment of bags.

\section{CONCLUSION}

India has established itself as a internet food businessperson with a regular balance of trade surplus in food and agricultural product. tho' the country remains vulnerable to production and worth shocks for varied commodities, the food process sector is growing at a median rate of eight p.c each year. it's expected to any grow because of increase in domestic consumption, dynamical trends in markets, shopper preferences for added product and growing capabilities. India ranks second in terms of global food production and are the world's largest producer of many commodities. However, compared to international trends, a negligible quantity of manufacture is processed in Asian nation thanks to key challenges like an absence of advanced process technologies, market disconnects and a lacking provide chain infrastructure. Food wastage remains a critical challenge, and an estimated 40 percent of perishable produce goes to waste.

\section{REFERENCES}

1. Sunil Kumari and Preeti Devi (2016) "Foreign Direct Investment on Indian Agriculture" p-ISSN: 2394-1545; e-ISSN: 2394-1553; Volume 3 Issue 7; July-September, 2016, pp. 748-752.

2. Epaphra, M (2017) "Analysis of Foreign Direct Investment, Agricultura Sector and Economic Growth in Tanzania" ISSN Online: 2152-7261 ISSN Print: 2152-7245

3. Dadson Awunyo-Vitor and Ruby Adjoa Sackey (2018) "Agricultural sector foreign direct investment and economic growth in Ghana"

4. Adekunle and E Oludayo (2018) Foreign Direct Investment Inflow and Agricultural Sector Productivity In Nigeria IOSR Journal of Economics and Finance (IOSR-JEF) e- ISSN: 2321-5933, p-ISSN: 2321-5925. Volume 9, Issue 4 Ver. PP 12-19.

5. Munisamy Gopinath (2010) "Foreign direct investment and wages: a cross-country https://doi.org/10.1080/0963819032000132067.

6. Tanay Kumar Nandi and Ritankar Sahu (2007) "Foreign direct investment in India with special focus on retail trade"

7. Sumei Tang and E. A. Selvanathan (2008) "Foreign Direct Investment, Domestic Investment and Economic Growth in China: A Time Series Analysis"

8. https://www.imarcgroup.com/farm-agricultural-equipments-industry-ind ia

9. https://community.data.gov.in/fdi-equity-inflows-in-agricultural-machin ery-sector-from-2000-01-to-2016-17/

10. https://www.ripublication.com/gjfm16/gjfmv8n2_02.pdf

11. https://pib.gov.in/newsite/PrintRelease.aspx?relid=191212

12. https://business.mapsofindia.com/fdi-india/sectors/agriculture-services.ht $\mathrm{ml}$

13. https://www.indianmirror.com/indian-industries/agricultural.html

14. https://www.imarcgroup.com/farm-agricultural-equipments-industry-ind ia

15. https://www.google.com/search? $\mathrm{q}=$ factors+and+challenges+in+the+Indi an+agricultural+equipments+market\&rlz=1C1CHZL_enIN779IN779 $\& o q=$ factors+and+challenges+in+the+Indian+agricultural+equipments +market\&aqs=chrome..69i57.3303j0j8\&sourceid=chrome\&ie=UTF-8

16. https://shodhganga.inflibnet.ac.in/bitstream/10603/96165/6/06_chapter 1.pdf

17. https://www.quora.com/What-are-competition-issues-in-the-agriculturalsector-in-India

18. https://www.thehindubusinessline.com/economy/foreign-direct-investme nt-up-28-in-april-june-2019/article29340468.ece 